Boise State University

ScholarWorks

Civil Engineering Faculty Publications and

Presentations

Department of Civil Engineering

$1-1-2018$

Addressing Clay Mineralogy Effects on Performance of Chemically Stabilized Expansive Soils Subjected to Seasonal Wetting and Drying

Bhaskar C.S. Chittoori

Boise State University

Anand J. Puppala

University of Texas at Arlington

Aravind Pedarla

University of Texas at Arlington

This is an author-produced, peer-reviewed version of this article. The final, definitive version of this document can be found online at Journal of Geotechnical and Geoenvironmental Engineering, published by the American Society of Civil Engineers. Copyright restrictions may apply. doi: 10.1061/(ASCE)GT.1943-5606.0001796 


\title{
Addressing Clay Mineralogy Effects on Performance of Chemically Stabilized Expansive Soils Subjected to Seasonal Wetting and Drying
}

\author{
Bhaskar C. S. Chittoori, Ph.D., PE \\ Assistant Professor \\ Department of Civil Engineering \\ Boise State University \\ Boise, ID \\ bhaskarchittoori@boisestate.edu
}

\author{
Anand J. Puppala, Ph.D., PE \\ Distinguished Teaching Professor and Associate \\ Dean \\ Department of Civil Engineering \\ The University of Texas at Arlington \\ Arlington, Texas
}

\author{
Aravind Pedarla, Ph.D., PE \\ Post-Doctoral Fellow \\ Department of Civil Engineering \\ The University of Texas at Arlington \\ Arlington, Texas
}

\begin{abstract}
Premature failures in chemically stabilized expansive soils cause millions of dollars in maintenance and repair costs. One of the reasons for these failures is the inability of existing stabilization design guidelines to consider the complex interactions between clay minerals and the stabilizers. It is vital to understand these complex interactions, as they are responsible for the strength improvement and swell/shrink reduction in these soils, in turn affecting the overall health of the infrastructure. Hence, this research study examined the longevity of chemically stabilized expansive soils subjected to wetting/drying conditions with a major focus on clay mineralogy. Eight different natural soils with varying clay mineralogy were subjected to wetting/drying durability studies after stabilizing with chemical additives including quicklime and cement. Performance indicators such as volumetric strain and Unconfined compressive strength trends were monitored at regular intervals during the wetting/drying process. It was observed that clayey soils dominant in the mineral Montmorillonite were susceptible to premature failures. It was also noted that soils dominant in other clay minerals exhibited early failures at lower additive contents. Also, an attempt was made for the first time to address the field implications of the laboratory studies by developing a correlation that predicts service life in the field based on clay mineralogy and stabilizer dosage.
\end{abstract}

Keywords: soil stabilization, durability, seasonal changes, clay mineralogy, expansive soils, volumetric strain

\section{Introduction}

Problematic expansive clays are often stabilized with chemical additives such as lime and cement to subdue the ill effects of swelling and shrinking (Nelson and Miller 1992; Puppala et al. 2005; Rogers and Wright 1986; Sherwood 1993; Little and Nair 2009). This technique is widely used in the construction of roads, airports, embankments, and canal linings built on or using expansive clays. In these cases, chemicals are mixed with the soil to improve workability, strength, stiffness, swelling characteristics and bearing capacity (Puppala et al. 2006, 2009; De Bel et al. 2009; Pedarla et al. 2011; Yi et al. 2016). For chemical treatment, soil property enhancements usually occur through chemical gel formation and bonding among soil particles along with a reduction in soil water affinity characteristics (Jones and Holtz 1973; Petry and Armstrong 1989; Al-Rawas, 2005; Chittoori 2008).

Chemical stabilization design guidelines for stabilizing expansive soils (AF-JMAN/TM 1994; InDOT 2008; Little and Nair 2009; TxDOT 2005) typically recommend a minimum strength requirement that should be met after stabilization and that the durability of the stabilization is checked. Even after following these stabilization design guides, several 
This is an author-produced, peer-reviewed version of this article. The final, definitive version of this document can be found online at Journal of Geotechnical and Geoenvironmental Engineering, published by the American Society of Civil Engineers. Copyright restrictions may apply. doi: 10.1061/(ASCE)GT.1943-5606.0001796

agencies have reported premature failures, especially in the case of pavement infrastructure. These early failures are typically attributed to the loss of stabilizer, caused by seasonal changes. However, in some instances, they could be due to a stabilizer being ineffective in some soils while other soils with the same index properties respond well to that stabilizer. This is a clear indication that the current stabilizer design procedures are not entirely equipped to stabilize all types of expansive soils since these guidelines recommend the selection of type and amount of the stabilizer based on the plasticity index (PI) and gradation characteristics of the soil.

The long-term behavior of chemically treated soil is more dependent on the complex interactions between the mineralogy of the soil and the chemical additive, along with environmental impacts (Allam and Sridharan 1981; Pile and Mc Innes 1984; Day 1994; Lin and Benson 2000; Chittoori 2008; Pedarla et al. 2011). Current stabilization design guidelines do not consider these mineralogical characteristics and therefore cannot capture the difference in performance (Chittoori 2008; Pedarla et al. 2011). Hence, this study attempted to understand the long-term behavior of chemically stabilized expansive soils by focusing on the clay minerals and their interactions with chemical additives. This paper presents the details of the various durability tests conducted in this research study and the results obtained from these tests. An analysis of these results is presented highlighting the importance of clay mineralogy and the shortcomings of existing stabilization guidelines along with a discussion on the development of a correlation to predict field implications of the laboratory studies conducted in this research.

\section{Documented Durability Studies}

Several studies were performed to understand the effect of seasonal moisture fluctuations and their relative volumetric changes on long-term performance of chemically stabilized expansive clays (Dif and Bluemel 1991; Lin and Benson 2000; Rao et al. 2001; Guney et al. 2007; Khattab et al. 2007; Cui et al. 2011; Pedarla et al. 2011). A brief overview of some of these studies is presented in the following sections followed by shortcomings of these studies.

Rao et al. (2001) conducted a study to assess the long-term performance of stabilized black cotton soils. These black cotton soils were stabilized with waste materials such as wood ash and organic matter (known as ash-modified soils) and also with the lime stabilizer. This study was primarily conducted to understand the relative effectiveness of ashmodified soils and lime- treated black cotton soils. They observed that the ash-modified soil became more porous due to cyclic wetting/drying and consequently collapsed significantly. They also found that due to cyclic wetting/drying the beneficial strength effects attributed from lime treatment were partially lost. Hoyos et al. (2005) performed a series of wet and dry cyclic tests on different types of chemically-treated sulfate soils to evaluate the strength, stiffness, and volume change property variations with these cycles. It was observed that higher dosages of stabilizer improved UCS, stiffness, and durability of the specimens.

Guney et al. (2007) performed cyclic wetting/drying (from here on referred to as W/D) experiments to observe the effect of lime stabilization on the swelling potential of the soil. In this study, both swelling potential and swelling pressure tests were performed on untreated and lime-treated soil specimens subjected to cyclic W/D. They observed that the primary benefits of lime stabilization were lost after the first W/D cycle, and the swelling potential increased for subsequent cycles. Khattab et al. (2007) conducted both W/D and leaching studies on bentonite (a highly expansive clay mineral) stabilized with $4 \%$ lime additive. They observed that during the W/D process, the samples that were initiated with the wetting stage had lower swell potentials than the samples that were started with the drying stage.

Cui et al. (2011) conducted a study to understand the effect of soil aggregate size and W/D on the stiffness of limestabilized expansive soils. In this study, they observed that soils with finer aggregate sizes had higher soil stiffness after lime treatment. Also, it was found that W/D increased the soil stiffness of lime-treated soils while it reduced the stiffness of untreated soils. It should be noted here that Cui et al. (2011) conducted only five cycles of W/D, and during the drying process, the samples were air-dried to their initial gravimetric moisture content, and not oven dried to constant weight.

From the above studies, it can be understood that W/D, due to seasonal moisture fluctuations, leads to poor performance of the stabilization, thereby causing failures to the structures built on them. However, very limited information is available to understand the mechanisms causing these failures, and most of the research studies did not examine the effects of clay minerals of test soils on the process of W/D. It is crucial to understand the role of the clay minerals on the durability of a chemical stabilization, as these clay minerals participate in the chemical reactions that form pozzolanic compounds to strengthen the soil. The design methods need to be examined by incorporating clay 
This is an author-produced, peer-reviewed version of this article. The final, definitive version of this document can be found online at Journal of Geotechnical and Geoenvironmental Engineering, published by the American Society of Civil Engineers. Copyright restrictions may apply. doi: 10.1061/(ASCE)GT.1943-5606.0001796

mineralogy and durability of the treatment studies. For this purpose, eight different soils with varying clay mineralogies were selected for this study and to address their long-term performance when subjected to W/D cycles. Durability tests revealed the ineffectiveness of stabilizer as many soils failed after certain W/D cycles. This study addresses the inefficiency in stabilization and the factors contributing. To predict the field design life, a parameter called "Field Survival Years" is determined based on "Montmorillonite-Lime ratio" which is obtained from the systematic durability evaluation of clays.

\section{Experimental Program}

The experimental program consisted of testing eight different soils with varying clay mineralogies. Stabilization design was performed on these soils as per the current procedures detailed in the manual "Modification and Stabilization of Soils and Base for Use in Pavement Structures" (TxDOT 2005). Initially, a quick lime additive was used as a stabilizer for all eight soils, and the additive dosage for each of the soils was established using the current stabilization design guides. Durability studies were performed in the laboratory in accordance with ASTM D 559. Following sections detail the experimental testing procedure followed to evaluate the stabilized clayey specimens for long-term performance. Later, four of the soils that showed premature failures under the durability studies were selected, and additional mix designs were performed on these soils by increasing the lime dosage to arrive at a durable mix design that satisfied the durability criterion. Furthermore, durability studies were also conducted on these four soils by using cement as an additive to establish at what dosage levels cement would be adequate for these soils. The details of the experimental program are presented in the following sections.

\section{$\underline{\text { Materials and Methods }}$}

A total of eight soils with soluble sulfate contents less than $50 \mathrm{ppm}$ and varying plasticity characteristics were selected from different parts of Texas with assistance from the Texas Department of Transportation (TxDOT) districts. The soils were named after the region from which they were obtained, as shown in Table 1. Physical or index and chemical properties of all the eight soils were determined using standard test procedures. Physical or index properties obtained for these soils included Atterberg limits (ASTM D4318) and gradation curve (ASTM D4693 - Sieve analysis; ASTM D422 - Hydrometer analysis), and these results are presented in Table 1. The chemical properties consisted of cation exchange capacity, specific surface area, and total potassium, as suggested by Chittoori and Puppala (2011), to obtain the clay mineralogy information of the soils. The dominant clay mineral and approximate clay mineral percentages of the minerals kaolinite, illite and Montmorillonite were obtained by following the method outlined by Chittoori and Puppala (2011). These results are presented in Table 2. Two types of additives/stabilizers, lime, and cement were studied in this research. The cement used in this study was Portland cement as per ASTM C 150 type I, while the lime used was quicklime.

\section{$\underline{\text { Mix Design }}$}

Mix design was performed as per the highway agency test protocols namely TEX-121E method for soils stabilized with lime and as per TEX-120E method for soils stabilized with cement. For the soils stabilized with lime, an initial estimate of the amount of lime was made via $\mathrm{pH}$ test or the Eades and Grim test (Eades and Grim, 1966). Once an initial estimate was made, optimum moisture contents (OMC) and maximum dry unit weights (MDUW) for varying soil-lime combinations with additive content higher than that determined by $\mathrm{pH}$ test were obtained. The OMC and MDUW for each soil-additive combination were determined by conducting standard Proctor's compaction test, as per ASTM D698. Unconfined Compressive Strength (UCS) tests, as per ASTM D2166, were performed on samples prepared at OMC and MDUW to determine the appropriateness of the stabilizer and its content based on the strength requirements per TEX-121E, which recommends a UCS value of more than $345 \mathrm{kPa}(50 \mathrm{psi})$. A similar procedure was followed for soils stabilized with cement, except that no $\mathrm{pH}$ testing was performed and the procedure outlined in TEX-120E was followed. Table 3 presents the type and the amount of stabilizer selected for each of the eight soils used in this research, along with their dominant clay minerals, MDUW and OMC.

\section{Sample Preparation}

Specimens of each soil/additive combination to be tested for durability studies were prepared at the optimum moisture content and maximum dry unit weight condition, as obtained during the mix design process. Samples were prepared using the static compaction method instead of the dynamic compaction method. The dynamic compaction method was 
This is an author-produced, peer-reviewed version of this article. The final, definitive version of this document can be found online at Journal of Geotechnical and Geoenvironmental Engineering, published by the American Society of Civil Engineers. Copyright restrictions may apply. doi: 10.1061/(ASCE)GT.1943-5606.0001796

avoided because this approach requires the soil to be compacted in layers, which hinders the process of saturation during moisture conditioning resulting from loss of pore connectivity due to layering from impact compaction method. The static method of sample preparation is done according to the procedure outlined in AASHTO T-307. The prepared samples were wrapped in plastic wrap to avoid moisture digress or ingress and cured in a $100 \%$ humidity room for seven days at a temperature of $25^{\circ} \mathrm{C}$. Higher temperature curing would reduce the time required for pozzolanic compound formation (Zhang et al. 2014). Following the seventh day of curing, the samples were taken out of the moisture room, the plastic wrap was removed, and durability tests were then performed.

\section{Durability Testing}

The procedure outlined by ASTM D559 method was closely followed, which simulates both wet and dry cycle conditions close to field conditions in a reasonably short period. According to the ASTM D559 method, the soil specimens should be prepared and cured, then submerged in water for 5 hours for wetting cycle, then oven dried at $71^{\circ} \mathrm{C}\left(160^{\circ} \mathrm{F}\right)$ for 42 hours for the drying cycle. A schematic of the test setup used in this research is presented in Figure 1.After removal from the oven, the specimen is subjected to volume change and moisture content measurements. The procedure is repeated for a total of 21 wet-dry cycles or until the sample failed. The soil specimens were allowed to swell and shrink in both lateral and vertical directions during both wetting and drying cycles, as prior studies by Punthutaecha et al. (2006) noted that the volumetric swell/shrink strains measured in the laboratory with no lateral or vertical restraints were in closer agreement with the field measured values than those obtained by restraining the lateral movement. The vertical movement was measured with the help of a dial gauge, while the radial movements were measured using a "pi tape."

A sample is deemed to have failed when 1) UCS of the sample tested is close to zero; 2) the sample crumbles under its own weight and hence no further testing can be performed; 3 ) the sample becomes so sensitive that it can be crumbled/crushed during sample handling activities, including moving sample from the oven to the water bath and/or making volumetric measurements.

In this study, a mix design or soil/additive combination is considered to be effective if the soil samples prepared using a particular mix design would last all 21 cycles and retaining at least $50 \%$ of the initial strength at the beginning of wetting/drying. Unconfined compressive strengths were performed on control and stabilized soil samples as per ASTM D2166. As the UCS tests were destructive tests, a total of five (5) soil samples were prepared so that each sample could be tested at $0,3,7,14$ and $21 \mathrm{~W} / \mathrm{D}$ cycles for each soil-additive combination. Duplicate specimens were used for obtaining each data point; thus, a total of 10 samples were cast for each of the soil/additive combinations. Each data point in the plots is an average of two test results. It should be noted here that UCS tests were performed after the corresponding wetting cycle and since the samples are saturated after this cycle the control sample at 0 cycles was also tested after saturating the sample.

\section{Additional Durability Studies}

Soils that did not perform well after stabilization, using the current design procedures were further analyzed with different additive types varying dosages to determine which stabilizer dosage combination would be effective for these soils. Based on these observations, an alternative procedure for determining stabilizer type and dosage based the mineralogy and other index properties of a given soil were developed.

For example, Austin soil, which has a PI of 34 , was not stabilized effectively when $6 \%$ lime was used as a stabilizer due to the high Montmorillonite content (40\%) present in its clay fraction. This soil was retested with an increased dosage of lime (8\%) and two dosages of cement (3\% and 6\%). The soil specimens were tested for strength after different cycles of durability to check the retained strength. Similar tests were also conducted on Pharr-A, Pharr-B, and Fort Worth soil specimens, and Table 4 summarizes various mix designs performed on these soils. Following the procedures described earlier, these soil specimens were subjected to alternate wetting and drying studies.

\section{Summary of W/D Test Results}

Volumetric strain changes were measured at the beginning and the end of each wetting and drying cycle. Percentage changes in volume after the corresponding cycle of W/D were calculated for each sample based on the initial sample dimensions (before the W/D cycles started). Strength tests were performed after 3, 7, 14 and 21 cycles of W/D. The 
This is an author-produced, peer-reviewed version of this article. The final, definitive version of this document can be found online at Journal of Geotechnical and Geoenvironmental Engineering, published by the American Society of Civil Engineers. Copyright restrictions may apply. doi: 10.1061/(ASCE)GT.1943-5606.0001796

percentage of retained strength after a corresponding W/D cycle is calculated by dividing the current UCS strength with the 0 cycle UCS strength before the first W/D cycle and after seven days of curing and is expressed as a percentage.

For the sake of being concise, the volumetric strain results are presented in groups. The soils are pooled into three groups, based on their mineral dominance in their clay fraction. Group-I consisted of four soils: namely, Austin, Fort Worth, Paris and Pharr-A (high PI), whose clay fraction was dominated by the presence of the mineral Montmorillonite. Group-II consisted of three soils from Bryan, Keller, and Pharr-B (medium PI), whose clay fraction was dominated by the presence of the mineral kaolinite. Group-III only consisted of only one soil from El Paso, which was dominant in the mineral illite. The volumetric strain and the UCS strength variation with W/D cycles are presented in the following sections.

\section{Volumetric Strain Data}

Volumetric strain results for Group-I, Group-II and Group-III soils are presented in Figures 2, 3, and 4, respectively. It can be observed from these three figures that the treated soils had lower volumetric strains than the untreated soils, which was expected. Soils that survived all 21 cycles with minimal volumetric changes $(<10 \%)$ are considered to have performed well under wetting/drying durability conditions.

It can be observed from Figures 2(a) and 2(b) that Austin and Fort Worth soils survived for a total of 12 and 11 cycles of durability, respectively, when treated with $6 \%$ lime. Similarly, Paris soil samples treated with $8 \%$ lime survived for only seven durability cycles, and this can be observed in Figure 2(c). Figure 2(d) shows that Pharr A soil samples survived for four W/D cycles when treated with $4 \%$ lime. It is apparent that none of Group-I soils mentioned above survived entire W/D testing. Premature failure in one soil (Pharr A) is attributed to the low initial dosage used. Nevertheless, all Group-I soils experienced early failures as these soils are predominant with Montmorillonite mineral.

Keller and Bryan soils, which fall under Group-II, survived all 21 W/D cycles when treated with $6 \%$ and $8 \%$ lime, respectively. However, Pharr-B soil samples, which belong to the same group, survived only $8 \mathrm{~W} / \mathrm{D}$ cycles when treated with 3\% lime. This can be clearly seen in Figure 3(c). Finally, El Paso soil, which belongs to Group-III, survived all $21 \mathrm{~W} / \mathrm{D}$ cycles when treated with $8 \%$ lime. It can also be observed from Figure 2 that the treated soils did not survive all 21 cycles, while in Figure 3 and Figure 4, all soils survived 21 W/D cycles except for the Pharr-B soil shown in Figure 3(c).

\section{Unconfined Compression Strength Results}

UCS data obtained for Group-I, Group-II and Group-III soils are presented in Figures 5, 6, and 7, respectively. Figures 5(a) and 5(b) show that Austin and Fort Worth soil specimens treated with 6\% lime dosage did not retain any strength after 12 and $11 \mathrm{~W} / \mathrm{D}$ cycles, respectively. Also, Paris soil treated with 8\% lime, lost all of its strength after eight W/D cycles (see Figure 5(c), while Pharr A soil specimens treated with $4 \%$ lime lost all of their strength after four durability cycles, as seen in Figure 5(d). Figures 6(a) and 6(b) show that both Bryan and Keller soil specimens treated with 8\% and $6 \%$ lime, respectively lasted all $21 \mathrm{~W} / \mathrm{D}$ cycles and retained over $85 \%$ of their initial strength. Pharr-B soil specimen treated with $3 \%$ lime failed to retain any strength after eight durability cycles, as shown in Figure 6(c). Lastly, Figure 7 shows that El Paso soil specimen treated with $8 \%$ lime retained $85 \%$ of its initial strength after 21 W/D cycles. Table 5 summarizes the retained strength measurements, along with the maximum volumetric strain change at the end of the number of W/D cycles survived, for all the eight soils.

\section{Analysis and Discussion}

As explained earlier, based on the above results, four soils that did not perform well under W/D durability were further tested, and these results are summarized in Table 6. All the above results are analyzed for the effects of clay mineralogy, additive type and additive dosage in the following sections. 
This is an author-produced, peer-reviewed version of this article. The final, definitive version of this document can be found online at Journal of Geotechnical and Geoenvironmental Engineering, published by the American Society of Civil Engineers. Copyright restrictions may apply. doi: 10.1061/(ASCE)GT.1943-5606.0001796

\section{Effect of Soil Type}

Table 5 shows that Austin, Fort Worth, Paris and Pharr-clays, which have high amounts of the Montmorillonite mineral in their clay fractions, did not survive all 21 W/D cycles. Clays from El Paso, Bryan, and Keller have other clay minerals (Illite or Kaolinite) as the dominant mineral in their clay fraction, and these clays survived all 21 cycles. This indicates that soils containing Montmorillonite as a dominant mineral are more susceptible to premature strength failures after chemical stabilization when they are exposed to volume changes caused by moisture movements. It should be noted here that though the Pharr-B soil is dominant in the mineral kaolinite, it lasted for only eight cycles primarily because of the low additive dosage (3\% lime). To further understand the effect of the mineral Montmorillonite on the durability of stabilization, the retained strengths and volumetric strain changes after $7 \mathrm{~W} / \mathrm{D}$ cycles for all the soils treated with $8 \%$ lime are plotted in Figure 8. It can be observed from this figure that, as the percent of Montmorillonite increases in the clay fraction, the retained strength after $7 \mathrm{~W} / \mathrm{D}$ cycles decrease, while the volumetric strain change increases. This is an important finding, as it shows the influence of clay mineralogy on the durability of chemical stabilizer in providing sustained strength over a long time period. A similar figure was plotted against the plasticity index of these soils and is presented in Figure 9. This figure clearly shows that the current approach of PI-based chemical stabilizer design does not provide any insights into the chemical stabilizer durability.

It was observed in this study that the samples that retained at least $80 \%$ of their initial strength after $7 \mathrm{~W} / \mathrm{D}$ cycles lasted for all $21 \mathrm{~W} / \mathrm{D}$ cycles, retaining at least $50 \%$ of the initial strength. Based on this observation, it can be deduced from Figure 8 that soils containing more than $40 \%$ of the Montmorillonite mineral in their clay fraction may not be efficiently stabilized with lime, as these soils could not be stabilized effectively using $8 \%$ lime, which is considered the upper limit for stabilization purposes, and higher amounts may not be economical.

\section{Effect of Additive Type}

The four soils that were selected for further evaluation were treated with both lime and cement as the lime treated soils after using as much as $8 \%$ by dry weight of the soil did not perform well in the long-term. Hence, these samples were treated with cement to assess what percentage of cement would effectively treat these soils. Based on these tests performance comparison between additive types is performed as follows.

Figure 10 presents a comparison of the number of W/D cycles samples survived for both cement and lime additives. In this figure, the amount of lime and cement used was $6 \%$ by dry weight of the soil. It can be observed from the figure that cement stabilization has outperformed lime stabilization for all four soils studied here. Though the state of practice is to use lime for high plastic soils and cement for granular soils, in this research, it was observed that for long-term durability of the stabilization cement performs better than lime. Authors attribute this to enhanced strength of the treated soil mixture which resisted stresses generated during wetting and drying cycles. This has been the main reason for cement treated soils with 6\% cement additive showing consistent and lower volumetric strains during the present experimental program.

\section{Effect of Additive Dosage}

Table 7 summarizes the effect of the amount of dosage on the long-term performance of a stabilized subgrade under seasonal moisture variations and volumetric movements due to these moisture fluctuations. Two soils were selected for this analysis, Pharr-A dominant in the mineral Montmorillonite and Pharr-B dominant in the mineral kaolinite. Pharr-A was treated with $4 \%, 6 \%$ and $8 \%$ of lime, while Pharr-B was treated with $3 \%, 6 \%$ and $8 \%$ of lime. It can be observed from the table that as the lime dosage increased, the stabilization effectiveness of Pharr-B soil improved considerably, making the samples last longer with the increase in dosage. In the case of Pharr-A soil, the stabilization effect lasted longer when the dosage was increased from 4 to $8 \%$, however even at $8 \%$ lime the samples only lasted $14 \mathrm{~W} / \mathrm{D}$ cycles. Hence, it can be understood from this exercise that for soils dominant in the kaolinite mineral (in this case Pharr-B soil); lower dosage levels can lead to premature failures, while higher dosage can assure long-term performance. The same is not true for Montmorillonite-dominant soils (in this case Pharr-A) where higher dosage did not result in better performance.

One important observation on Montmorillonite rich soils is that if these soils are restrained in volume changes due to higher confinements (assuming treatments are done at medium range depths of 1 to $2 \mathrm{~m}$ ), then the durability performance will be improved (Pedarla 2009). If the treatments are to be done at shallow depths within top $0.6 \mathrm{~m}$ of 
This is an author-produced, peer-reviewed version of this article. The final, definitive version of this document can be found online at Journal of Geotechnical and Geoenvironmental Engineering, published by the American Society of Civil Engineers. Copyright restrictions may apply. doi: 10.1061/(ASCE)GT.1943-5606.0001796

subgrade, then it is recommended to replace the montmorillonite-rich soils with quality fill material. Other methods of amending the natural soils with sand or other inert materials may also provide better W/D performance, but those studies are not considered in this research, and hence no recommendations on those amendments can be made.

\section{Limitations of Existing PI-Based Design Methodologies}

So far in this research study, soils stabilized using the current stabilization design procedures did not survive the seasonal moisture fluctuations studied by conducting W/D durability tests. The current stabilizer selection criterion, followed by various state and federal agencies including TxDOT, FHWA, and the United States Army Corps of Engineers are based on the plasticity index (PI) and gradation characteristics of the soil. These organizations have reported problems with subgrade failures due to a stabilizer being ineffective in some soils while other soils, with the same index properties, respond well to that stabilizer. In this study, a similar response was observed between Bryan and Fort Worth soils, with similar PI's (31 and 29 respectively), when treated with the same amount of lime additive. As the PI values of these soils were similar, the existing stabilization guidelines recommended same type and amount of additive. However, Bryan soil that was dominant in kaolinite could survive all 21 cycles of W/D; whereas, Fort Worth soil, with Montmorillonite as a dominant clay fraction, survived only ten cycles of W/D. Hence, the selection of type and amount of stabilizer based on PI of the clay alone is not sufficient for effective stabilizer design. It is highly important to include the clay mineralogy information in the stabilizer design process to have durable and sustainable subgrade stabilization.

\section{Field Service Life Implications}

Based on the results obtained in this study, an effort was made to understand the implications of these laboratory studies in field service life assessments. For this purpose, researchers attempted to predict the service life of stabilization, defined as "Field Service Years" or FSY, using the ratio between, the percentage of Montmorillonite in clay fraction of the soil and the amount of lime used to stabilize the soil, defined as "Montmorillonite - Lime Ratio" or MLR. It should be noted that this analysis is approximate and is dependent on clay mineralogy and additive dosages. Also, the test database used is not comprehensive and more W/D studies with detailed mineralogy information will enhance the correlation developed in this research.

In the laboratory, the samples were dried 42 hours at $60^{\circ} \mathrm{C}$, and the samples are submerged under water for 5 hours, during which the samples reach saturation of 85 to $95 \%$. No studies have been conducted thus far to assess how many of these wetting and drying scenarios occur in a given year; hence we are assuming that, in a given year, there might be two such wetting/drying scenarios. Even though there might be several rainfall events, followed by dry periods in a given year, the basis for this conservative assumption is that the laboratory conditions replicated here were extreme and the field soil rarely becomes completely dry unless prolonged drought conditions persist. Please note that this kind of approximation is area specific and will vary for different regions. Nevertheless, this kind of analysis attempted here will give a perspective of correlating laboratory W/D cycles with the actual field performance data. Hence, in this research, based on the above-explained approximations, the present $21 \mathrm{~W} / \mathrm{D}$ cycles correspond to approximately ten years in the field conditions.

Figure 11 presents a plot of the ratio of percentage of Montmorillonite and the percentage of lime used for stabilization defined as "Montmorillonite - Lime Ratio" or MLR versus the Field Survival Years or FSY. FSY can be equated to the number of W/D cycles survived, divided by 2 (assuming two cycles per year). Assuming that the Montmorillonite percentages in the soil range from 10 to 80 in the clay fraction and the lime percentages range from 1 to 10 , the MLR values can range from 1 to 80 . An MLR value of 80 indicates an extreme worst-case scenario since the \%M in the soil is $80 \%$ and is treated with only $1 \%$ lime, while an MLR value of 1 indicates an extreme best case scenario where the $\%$ of $\mathrm{M}$ in the soil is only $10 \%$ while the soil was treated with $10 \%$ of lime. Other combinations are also possible, but for the discussion, not all scenarios are considered. Typical MLR values for Texas soils would range from 2 to 20, based on the soils tested in this research and standard practices. From Figure 11, it can be observed that for lower MLR values, the FSY was higher (at least ten years) while for higher MLR values, the FSY values decreased. Based on the soils tested in this research it can be deduced that an MLR value higher than five can lead to poor stabilization performance. Equation 1 presents a correlation between FSY and MLR based on the soils tested here and this equation has an R-squared value of 0.62 . Though this is not a generalized equation, it is important to note that this gives a rough estimate of field performance of similar soils, given the percentage of lime used for treatment. It should be noted here that the plot contains two data points that are considered outliers circled in Figure 11. These two data points contradict 
This is an author-produced, peer-reviewed version of this article. The final, definitive version of this document can be found online at Journal of Geotechnical and Geoenvironmental Engineering, published by the American Society of Civil Engineers. Copyright restrictions may apply. doi: 10.1061/(ASCE)GT.1943-5606.0001796

the previously established threshold value of MLR being less than or equal to 5 to be an indicator of optimal longterm performance. The data point to the right of the dotted line in Figure 11 is having higher MLR and still surviving all 21 cycles of W/D, while the data point on the left (circled in Figure 11) of the dotted line is having lower MLR but only surviving 14 cycles of wetting-drying. Further research is required to understand this phenomenon.

$$
\begin{gathered}
\text { FSY }=-0.8 \times \text { MLR }+12.2 \\
\text { where, } \\
\text { FSY }=\text { Field Service Years } \\
\text { MLR }=\text { Montmorillonite-Lime Ratio }
\end{gathered}
$$

\section{$\underline{\text { Future Research }}$}

The current research assumes that clay fraction contains Montmorillonite, illite, and kaolinite. However, other clay minerals like chlorites, and commonly occurring non-clay minerals such as quartz, feldspar, and mica, when present, might have profound effects on the stabilization behavior. This was not studied in this research.

Leaching of stabilizer during heavy rainfall events is another major aspect of the durability assessments. This aspect was studied in this research on a separate set of samples, and the results were presented in Chittoori et al. (2013). However, the authors believe that the wetting/drying and leaching are not mutually exclusive procedures and occur simultaneously in the field. Hence, it would be more insightful to conduct these two studies on the same sample, rather than on separate samples, and observe the changes. Hence, further research is warranted in this direction to design a versatile setup that can perform both W/D cycles and leaching cycles on the same sample, simultaneously, to provide the superior simulation of the field conditions.

\section{Summary and Conclusions}

Premature failures were reported in the field for various transportation-related infrastructures constructed on chemically stabilized expansive soils in different regions. Even though the expansive soils were stabilized following existing stabilization design guidelines, some soils performed as expected, while other soils did not. The reasons for this erratic behavior in treated expansive soils were unknown. Hence, a research study was undertaken to understand the reasons behind this behavior. For this purpose, a total of eight soils, with varying plasticity and mineralogical characteristics, were selected from various regions of Texas and subjected to wetting/drying durability studies. ASTM D 559 was closely followed for conducting the wetting/drying durability studies on each of these soils. Both volumetric strain and Unconfined compressive strength were measured at various numbers of W/D cycles. Mix design was initially performed on all eight soils following existing stabilization design guidelines, and the treated and control soil samples were subjected to W/D cycles, as explained earlier. Four of the soils, which did not perform well, were further treated with different dosages of lime and cement to arrive at a mix design that satisfies the durability criterion. Based on these test results, the following important conclusions can be made.

> Soils with similar plasticity characteristics do not have similar behaviors towards the same chemical treatment. This is clearly demonstrated in the case of Bryan and Fort Worth soils. Hence, it is important to know the mineralogical and plasticity characteristics of the soils.

$>$ The Montmorillonite mineral is an important influence in dictating the engineering behavior of stabilized expansive soils. Soils that contain low amounts of the Montmorillonite mineral survived all $21 \mathrm{~W} / \mathrm{D}$ cycles, while those with high amounts failed quickly after the W/D cycles started.

$>$ Soils containing more than $40 \%$ of the Montmorillonite mineral in their clay fraction may not be efficiently stabilized with lime, as $8 \%$ of lime is considered the upper limit for stabilization purposes, and anything beyond this may not be economical.

$>$ The effect of the additive type on the long-term performance of stabilized expansive soils was studied in this research. It has been observed that cement treatment survived a greater number of cycles compared to lime at similar dosage levels for all four soils that were retested to arrive at the durable performance. This finding is new and does not fall in line with current practice. 
$>$ A new empirical model was developed to predict the field service life of a stabilization based on soil type and the amount of additive used for stabilization. Based on this model an MLR value of 5 or lower is recommended for better field performance for the similar type of soils.

\section{Acknowledgements}

The authors would like to express their sincere appreciation to Texas Department of Transportation (TxDOT) for the support of this research. Authors would like to acknowledge Mark McDaniel of the TxDOT and Dr. Soheil Nazarian of the University of Texas at El Paso for their assistance with this research.

\section{References}

Allam, M. M., and Sridharan, S. (1981). "Effect of wetting and drying on shear strength.” J. Geotech. Engrg. Div., 107(4), 421-438.

Al-Rawas, A. A., Hago, A.W., Al-Sarmi, H. 2005. "Effect of lime, cement, and Sarooj (artificial pozzolan) on the swelling potential of an expansive soil from Oman.” Building and Environment, 40 (5), 681-687.

AF-JMAN/TM (1994). "Soil stabilization for pavements." TM 5-822-14/AFJMAN 32-1019, Department of The Army, The Navy, and the Air Force, Washington, DC.

Chittoori, B. (2008). "Clay mineralogy effects on long-term performance of chemically treated expansive clays." Ph.D., The University of Texas at Arlington, Arlington, TX.

Chittoori, B., Puppala, A., Wejrungsikul, T., and Hoyos, L. (2013). "Experimental Studies on Stabilised Clays at Various Leaching Cycles." Journal of Geotechnical and Geoenvironmental Engineering, 139(10), 16651675.

Chittoori, B., and Puppala, A. J. (2011). "Quantitative estimation of clay mineralogy in fine-grained soils." Journal of Geotechnical and Geoenvironmental Engineering, 137(11), 997-1008.

Cui, Y. J., Tang, A. M., and Vu, M. N. (2011). "Effects of the maximum soil aggregates size and cyclic wettingdrying on the stiffness of a lime-treated clayey soil." Géotechnique, 61(5), 421-429.

Day, R. W. (1994). “Swell-shrink behavior of compacted clay.” J. Geotech. Engrg., 120(3), 618-623.

Dif, A. E., and Bluemel, W. F. (1991). "Expansive soils under cyclic drying and wetting.” Geotech. Test. J., 14(1), 96-102.

Eades, J. L., and Grim, R. E. (1966). “A Quick Test to Determine Lime Requirements for Soil Stabilization.” Highway Research Record 139, HRB, National Research Council, Washington D.C., 61-72.

Guney, Y., Sari, D., Cetin, M., and Tuncan, M. (2007). "Impact of cyclic wetting-drying on swelling behavior of lime-stabilised soil." Building and Environment, 42(2), 681-688.

Hoyos L. R., A. Laikram and A. J. Puppala (2005) "Assessment of Seasonal Effects on Engineering Behavior of Chemically Treated Sulfate-Rich Expansive Clay", Proc., GEOPROB2005: International Conference on Problematic Soils, pp. 25-27.

InDOT (2008). "Design procedures for soil modification or stabilization." Indiana Department of Transportation.

Jones, D. E., and W. G. Holtz. Expansive Soils: The Hidden Disaster. Civil Engineering, TRB Vol. 43, 1973, pp. 49-51

Khattab, S., Al-Mukhtar, M., and Fleureau, J. (2007). "Long-Term Stability Characteristics of a Lime-Treated Plastic Soil." Journal of Materials in Civil Engineering, 19(4), 358-366.

Lin, L.-C., and Benson, C. H. (2000). "Effect of wet-dry cycling on swelling and hydraulic conductivity of GCLs." J. Geotech. Geoenviron. Eng., 126(1), 40-49.

Little, D. N., and Nair, S. (2009). "Recommended practice for stabilization of subgrade soils and base materials ", Web Document 144, National Cooperative Highway Research Program.

Nelson, J. D., and Miller, D. J. (1992). Expansive soils: problems and practice in foundation and pavement engineering, J. Wiley, New York.

Pedarla, A. (2009). "Durability Studies on Stabilization Effectiveness of Soils Containing Different Fractions of Montmorillonite.” Master thesis, University of Texas - USA, (December), 118.

Pedarla, A., Chittoori, S., and Puppala, A. (2011). "Influence of Mineralogy and Plasticity Index on the Stabilization Effectiveness of Expansive Clays." Transportation Research Record: Journal of the Transportation Research Board, 2212(-1), 91-99.

Pedarla, A., Chittoori, S., and Puppala, A. (2011). "Influence of Mineralogy and Plasticity Index on the Stabilization Effectiveness of Expansive Clays." Transportation Research Record: Journal of the Transportation Research Board, 2212, 91-99. 
This is an author-produced, peer-reviewed version of this article. The final, definitive version of this document can be found online at Journal of Geotechnical and Geoenvironmental Engineering, published by the American Society of Civil Engineers. Copyright restrictions may apply. doi: 10.1061/(ASCE)GT.1943-5606.0001796

Petry, T. M., and J. C. Armstrong. Stabilization of Expansive Clay Soils. In Transportation Research Record 1219, TRB, National Research Council, Washington, D.C., 1989, pp. 103-112.

Pile, K. C., and Mc Innes, D. E. (1984). “Laboratory technology for measuring properties of expansive clays.” Proc., 5th Int. Conf. on Expansive Soils, Australia, 85-93.

Punthutaecha, K., Puppala, A.J., Vanapalli, S.K., and Inyang, H. (2006). "Volume change behaviors of expansive soils stabilized with recycled ashes and fibers.” Journal of Materials in Civil Engineering, vol. 18(2), pp. 295-306.

Puppala, A.J., Chittoori, B.C.S., Talluri, N., Le, M., Bheemasetti, T., Thomey, J., 2013. "Stabilizer Selection for Arresting Surficial Slope Failures: A Sustainability Perspective.” ASCE GeoCongress, 2013, San Diego, California, pp. 1465-1474

Puppala, A. J., Saride, S., Potturi, A., and Hoyos, L. R. 2009. "Resilient behavior of cement-fiber treated reclaimed asphalt pavement (RAP) aggregates as bases .” Proc. Int. Found. Congress and Equipment Expo, ASCE, GSP 187, 433-440.

Puppala, A.J., Kadam, R., Madhyannapu, R. and Hoyos, L.R. 2006 "Small-Strain Shear Moduli of Chemically Stabilized Sulfate-Bearing Cohesive Soils”. Journal of Geotechnical and Geoenvironmental Engineering, Vol 132, pp. 322-336.

Puppala, A. J., Wattanasanticharoen, E., and Punthutaecha, K. (2005). "Experimental evaluations of stabilization methods for sulphate-rich expansive soils." Ground Improvement, 9(2), 89-90.

Rao, S. M., Reddy, B. V. V., and Muttharam, M. (2001). "The impact of cyclic wetting and drying on the swelling behavior of stabilised expansive soils." Engineering Geology, 60(1-4), 223-233.

Rogers, L. E., and Wright, S. G. (1986). The effects of wetting and drying on the long-term shear strength parameters for compacted Beaumont clay, Center for Transportation Research, Bureau of Engineering Research, the University of Texas at Austin, Austin.

Sherwood, P. T. (1993). Soil stabilisation with cement and lime: State of the art review, HMSO, London.

TxDOT (2005). "Guidelines for modification and stabilization of soils and base for use in pavement structures." Texas Department of Transportation.

Yi, Y., Liu, S., Puppala, A.J., 2016. "Laboratory Modelling of T-shaped Soil-cement Column for Soft Ground Treatment under Embankment.” Géotechnique 66, No. 1, 85-89 [http://dx.doi.org/10.1680/jgeot.15.P.019], ICE Publishers, January 2016.

Zhang, R. J., Lu, Y. T., Tan, T. S., Phoon, K. K., and Santoso, A. M. (2014). "Long-Term Effect of Curing Temperature on the Strength Behavior of Cement-Stabilized Clay." Journal of Geotechnical and Geoenvironmental Engineering, 140(8), 4014045.

\section{List of Tables}

Table 1 Soil classification and plasticity index for soils under study Error! Bookmark not defined.

Table 2 Chemical properties of the soils along with their clay mineralogies Error! Bookmark not defined.

Table 3 Type and amount of stabilizer selected for each soil along with their dominant clay mineral ...Error!

\section{Bookmark not defined.}

Table 4 Selected soils treated with additional stabilizer dosages Error! Bookmark not defined.

Table 5 Volumetric strain and retained strength at the end of wetting/drying cycles survived for all eight soils treated with lime. Error! Bookmark not defined.

Table 6 Summary of test results for soils treated with additional stabilizer dosages... Error! Bookmark not defined.

Table 7 Comparison of results between the additive dosages. Error! Bookmark not defined. 
Table 1 Soil classification and plasticity index for soils under study

\begin{tabular}{||c|c|c|c|c|c|c|c|c|c||}
\hline \hline \multirow{2}{*}{$\begin{array}{c}\text { S } \\
\text { No. }\end{array}$} & \multirow{3}{*}{ Soil Name } & \multicolumn{4}{|c|}{ Gradation, \% } & \multicolumn{3}{|c|}{ Classification } & \multicolumn{2}{|c|}{ Atterberg Limits } \\
\cline { 3 - 11 } & & Gravel & Sand & Silt & Clay & USCS & LL & PL & PI \\
\hline 1 & Austin & 0 & 5 & 38 & 57 & CH & 41 & 17 & 34 \\
\hline 2 & Bryan & 0 & 13 & 40 & 47 & CL & 45 & 14 & 31 \\
\hline 3 & El Paso & 0 & 37 & 42 & 21 & CL & 30 & 14 & 16 \\
\hline 4 & Fort Worth & 0 & 11 & 37 & 52 & CH & 61 & 32 & 29 \\
\hline 5 & Keller & 0 & 18 & 45 & 37 & CL & 25 & 14 & 11 \\
\hline 6 & Paris & 0 & 9 & 45 & 46 & CH & 60 & 24 & 36 \\
\hline 7 & Pharr-A & 0 & 2 & 39 & 59 & CH & 67 & 22 & 45 \\
\hline 8 & Pharr-B & 0 & 3 & 55 & 42 & CH & 56 & 19 & 37 \\
\hline
\end{tabular}

Note: PI - Plasticity Index; LL - Liquid Limit; PL - Plastic Limit; USCS - Unified Soil Classification System

Table 2 Chemical properties of the soils along with their clay mineralogies

\begin{tabular}{|c|c|c|c|c|c|c|c|c||}
\hline S No. & Soil Name & PI & CEC & SSA & TP & $\mathbf{\% I}$ & $\mathbf{\% K}$ & $\mathbf{\% M}$ \\
\hline 1 & Austin & 34 & 101 & 288 & 1.74 & 29 & 18 & 53 \\
\hline 2 & Bryan & 31 & 77 & 205 & 1.36 & 23 & 40 & 37 \\
\hline 3 & El Paso & 16 & 57 & 161 & 3.75 & 63 & 14 & 23 \\
\hline 4 & Fort Worth & 29 & 117 & 314 & 0.98 & 16 & 23 & 60 \\
\hline 5 & Keller & 11 & 71 & 133 & 1.1 & 18 & 62 & 20 \\
\hline 6 & Paris & 36 & 133 & 431 & 0.79 & 13 & 17 & 70 \\
\hline 7 & Pharr-A & 45 & 104 & 306 & 1.55 & 26 & 26 & 48 \\
\hline 8 & Pharr-B & 37 & 76.1 & 132 & 1.65 & 28 & 54 & 18 \\
\hline
\end{tabular}

Note: PI - Plasticity Index; CEC - Cation Exchange Capacity; SSA - Specific Surface Area; TP -

Total Potassium; \% - Illite percent in clay fraction; \% - Kaolinite percentage in clay fraction; \%M

- Montmorillonite percentage in clay fraction

Table 3 Type and amount of stabilizer selected for each soil along with their dominant clay mineral

\begin{tabular}{|c|c|c|c|c|c|c|}
\hline $\begin{array}{l}\text { S } \\
\text { No. }\end{array}$ & Soil & $\begin{array}{c}\text { Dominating clay } \\
\text { mineral }\end{array}$ & $\begin{array}{l}\text { Type of } \\
\text { additive }\end{array}$ & $\begin{array}{c}\text { Amount of } \\
\text { additive, (\% } \\
\text { by weight) }\end{array}$ & $\begin{array}{l}\text { MDUW } \\
\left(\mathbf{k N} / \mathbf{m}^{3}\right)\end{array}$ & $\begin{array}{c}\text { OMC } \\
(\%)\end{array}$ \\
\hline 1 & Austin & Montmorillonite & Lime & $6 \%$ & 17.1 & 20.4 \\
\hline 2 & Bryan & Kaolinite & Lime & $8 \%$ & 15.3 & 22.7 \\
\hline 3 & El Paso & Illite & Lime & $8 \%$ & 18.2 & 15.1 \\
\hline 4 & Fort Worth & Montmorillonite & Lime & $6 \%$ & 14.6 & 23.1 \\
\hline 5 & Keller & Kaolinite & Lime & $6 \%$ & 19.1 & 13.4 \\
\hline 6 & Paris & Montmorillonite & Lime & $8 \%$ & 13.7 & 24.3 \\
\hline 7 & Pharr-A & Montmorillonite & Lime & $4 \%$ & 13.4 & 31.0 \\
\hline 8 & Pharr-B & Kaolinite & Lime & $3 \%$ & 15.1 & 24.7 \\
\hline
\end{tabular}


This is an author-produced, peer-reviewed version of this article. The final, definitive version of this document can be found online at Journal of Geotechnical and Geoenvironmental Engineering, published by the American Society of Civil Engineers. Copyright restrictions may apply. doi: 10.1061/(ASCE)GT.1943-5606.0001796

Table 4 Selected soils treated with additional stabilizer dosages

\begin{tabular}{|c|c|c|c|}
\hline Soil & Additive & OMC* (\%) & $\begin{array}{c}\text { MDUW** } \\
\left(\mathbf{k N} / \mathbf{m}^{3}\right)\end{array}$ \\
\hline \multirow{4}{*}{ Pharr-B } & Control & 24.7 & 14.8 \\
\hline & $6 \%$ lime & 28.0 & 14.0 \\
\hline & $8 \%$ lime & 29.0 & 13.7 \\
\hline & $6 \%$ cement & 28.5 & 14.0 \\
\hline \multirow{4}{*}{ Austin } & Control & 20.5 & 16.7 \\
\hline & $6 \%$ lime & 21.0 & 14.9 \\
\hline & 3\% cement & 21.5 & 15.6 \\
\hline & $6 \%$ cement & 21.0 & 15.1 \\
\hline \multirow{5}{*}{ Pharr-A } & Control & 31.0 & 13.1 \\
\hline & $6 \%$ lime & 31.5 & 12.2 \\
\hline & 8\% lime & 32.5 & 11.9 \\
\hline & 3\% cement & 32.0 & 12.1 \\
\hline & $6 \%$ cement & 32.5 & 11.9 \\
\hline \multirow{4}{*}{ Fort Worth } & Control & 24.0 & 14.4 \\
\hline & $6 \%$ lime & 25.5 & 14.1 \\
\hline & $3 \%$ cement & 24.5 & 14.1 \\
\hline & 6\% cement & 25.0 & 14.0 \\
\hline
\end{tabular}

Table 5 Volumetric strain and retained strength at the end of wetting/drying cycles survived for all eight soils treated with lime

\begin{tabular}{||c|c|c|c|c|c||}
\hline Soil Name & $\begin{array}{c}\text { Dominating clay } \\
\text { mineral }\end{array}$ & $\begin{array}{c}\text { Amount of } \\
\text { additive, } \\
\mathbf{( \% ~ b y ~} \\
\text { weight) }\end{array}$ & $\begin{array}{c}\text { \# of cycles } \\
\text { sample } \\
\text { survived }\end{array}$ & $\begin{array}{c}\text { Volumetric } \\
\text { strain (\%) }\end{array}$ & $\begin{array}{c}\text { Retained } \\
\text { strength (\%) }\end{array}$ \\
\hline Austin & Montmorillonite & 6 & 12 & 15 & 0 \\
\hline Fort Worth & Montmorillonite & 6 & 10 & 15 & 0 \\
\hline Paris & Montmorillonite & 8 & 7 & 15 & 0 \\
\hline Pharr-A & Montmorillonite & 4 & 4 & 30 & 0 \\
\hline Bryan & Kaolinite & 8 & 21 & 6 & 93 \\
\hline Keller & Kaolinite & 6 & 21 & 5 & 0 \\
\hline Pharr-B & Kaolinite & 3 & 8 & 18 & 80 \\
\hline El Paso & Illite & 8 & 21 & 12 & 0 \\
\hline
\end{tabular}


This is an author-produced, peer-reviewed version of this article. The final, definitive version of this document can be found online at Journal of Geotechnical and Geoenvironmental Engineering, published by the American Society of Civil Engineers. Copyright restrictions may apply. doi: 10.1061/(ASCE)GT.1943-5606.0001796

Table 6 Summary of test results for soils treated with additional stabilizer dosages

\begin{tabular}{|c|c|c|c|c|c|}
\hline Soils & $\begin{array}{c}\text { Dominating } \\
\text { mineral }\end{array}$ & Stabilizer & $\begin{array}{l}\text { No. of cycles } \\
\text { the sample } \\
\text { survived }\end{array}$ & $\begin{array}{l}\text { Volumetric } \\
\text { strain (\%) }\end{array}$ & $\begin{array}{c}\text { Retained } \\
\text { strength } \\
(\%)\end{array}$ \\
\hline \multirow{5}{*}{ Pharr-B } & \multirow{5}{*}{ Kaolinite } & 3\% Lime & 8 & 18 & 0 \\
\hline & & 6\% Lime & 14 & 12 & 0 \\
\hline & & 8\% Lime & $21 *$ & 6 & 47 \\
\hline & & 3\% Cement & 14 & 10 & 0 \\
\hline & & 6\% Cement & $21 *$ & 4 & 59 \\
\hline \multirow{4}{*}{ Austin } & \multirow{4}{*}{ Montmorillonite } & 6\% Lime & 12 & 15 & 0 \\
\hline & & 8\% Lime & $21 *$ & 6 & 67 \\
\hline & & 3\% Cement & 14 & 10 & 0 \\
\hline & & 6\% Cement & $21 *$ & 4 & 80 \\
\hline \multirow{5}{*}{ Pharr-A } & \multirow{5}{*}{ Montmorillonite } & 4\% Lime & 4 & 30 & 0 \\
\hline & & 6\% Lime & 9 & 9 & 0 \\
\hline & & 8\% Lime & 14 & 7 & 0 \\
\hline & & 3\% Cement & 9 & 9 & 0 \\
\hline & & 6\% Cement & $21 *$ & 5 & 83 \\
\hline \multirow{4}{*}{ Fort Worth } & \multirow{4}{*}{ Montmorillonite } & 6\% Lime & 10 & 15 & 0 \\
\hline & & 8\% Lime & 14 & 8 & 57 \\
\hline & & 3\% Cement & 14 & 11 & 42 \\
\hline & & 6\% Cement & $21 *$ & 5 & 57 \\
\hline
\end{tabular}

* - Sample still intact

Table 7 Comparison of results between the additive dosages

\begin{tabular}{|c|c|c|c|c|c|}
\hline Soil type & $\begin{array}{c}\text { Mineral } \\
\text { Dominance }\end{array}$ & Additive type & $\begin{array}{c}\text { Amount of additive, } \\
\%\end{array}$ & \# of cycles survived & $\begin{array}{l}\% \text { Retained strength } \\
\text { after } 7 \text { W/D cycles }\end{array}$ \\
\hline \multirow{3}{*}{ Pharr-A } & \multirow{3}{*}{ Montmorillonite } & \multirow{3}{*}{ Lime } & 4 & 4 & 0 \\
\hline & & & 6 & 9 & 29 \\
\hline & & & 8 & 14 & 24 \\
\hline \multirow{3}{*}{ Pharr-B } & \multirow{3}{*}{ Kaolinite } & \multirow{3}{*}{ Lime } & 3 & 8 & 32 \\
\hline & & & 6 & 14 & 58 \\
\hline & & & 8 & 21 & 63 \\
\hline
\end{tabular}


This is an author-produced, peer-reviewed version of this article. The final, definitive version of this document can be found online at Journal of Geotechnical and Geoenvironmental Engineering, published by the American Society of Civil Engineers. Copyright restrictions may apply. doi: 10.1061/(ASCE)GT.1943-5606.0001796

\section{List of Figures}

Figure 1 Schematic and photographs of the wet/dry setup

Figure 2 Volumetric strain change with W/D cycles for Group I soils a) Austin soil $\quad$ b) Fort Worth soil c) Paris soil d) Pharr-A soil

Figure 3 Volumetric strain change with W/D cycles for Group II soils a) Bryan soil b) Keller soil c) Pharr-B soil Figure 4 Volumetric strain change with W/D cycles for Group III soil (El Paso)

Figure 5 Unconfined compression strength variation with W/D cycles for Group I soils a) Austin soil b) Fort Worth soil c) Paris soil d) Pharr-A soil

Figure 6 Unconfined compression strength variation with W/D cycles for Group II soils a) Bryan soil b) Keller soil c) Pharr-B soil

Figure 7 Unconfined compression strength variation with W/D cycles for Group III soil (El Paso)

Figure 8 Effect of Montmorillonite mineral on durability lime stabilization

Figure 9 Effect of plasticity index on durability of lime stabilization

Figure 10 Effect of additive type on the W/D performance of chemical stabilization

Figure 11 MLR based FSY predictions for the tested soils 

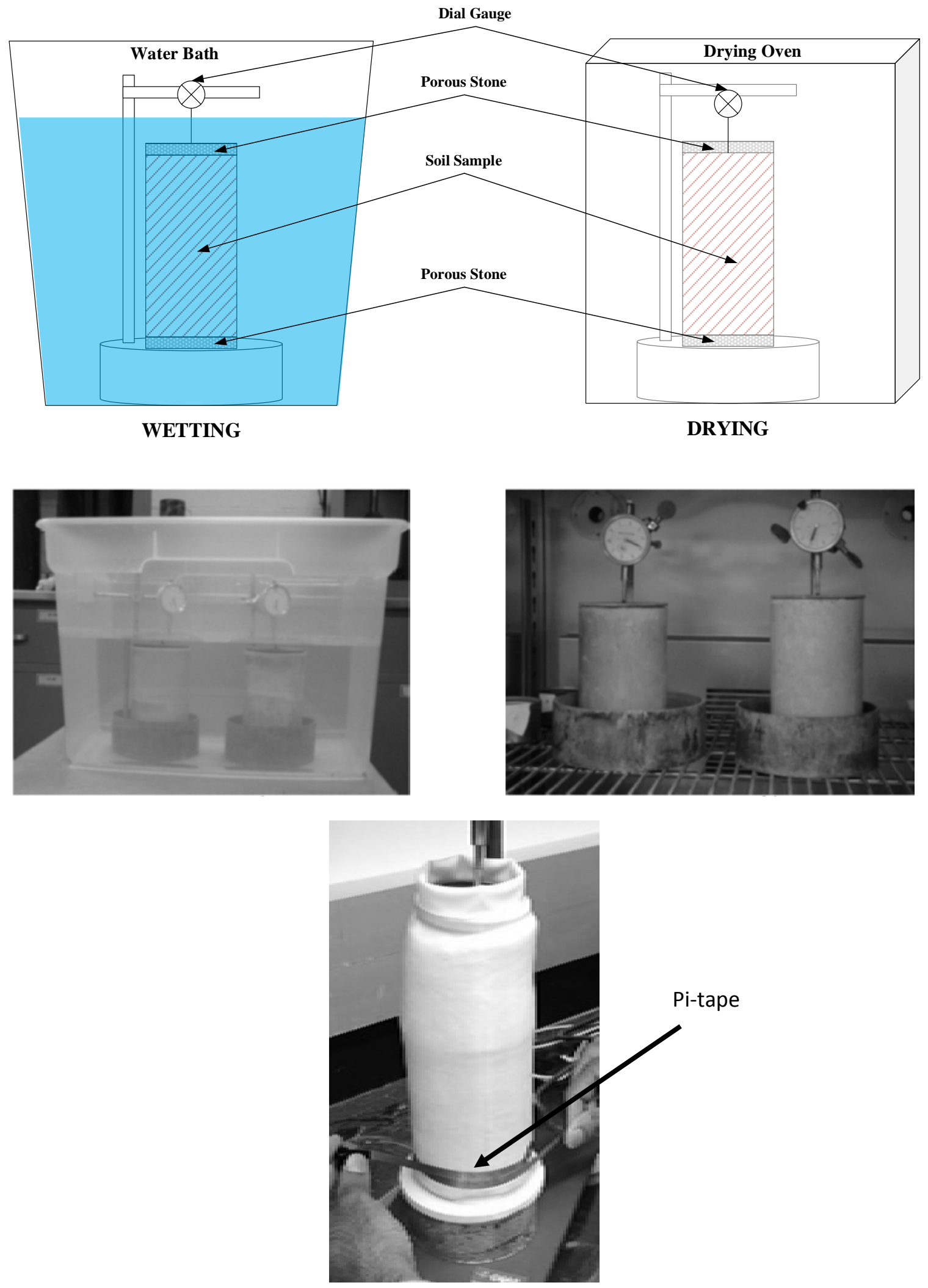

Figure 1 Schematic and photographs of the wet/dry setup 


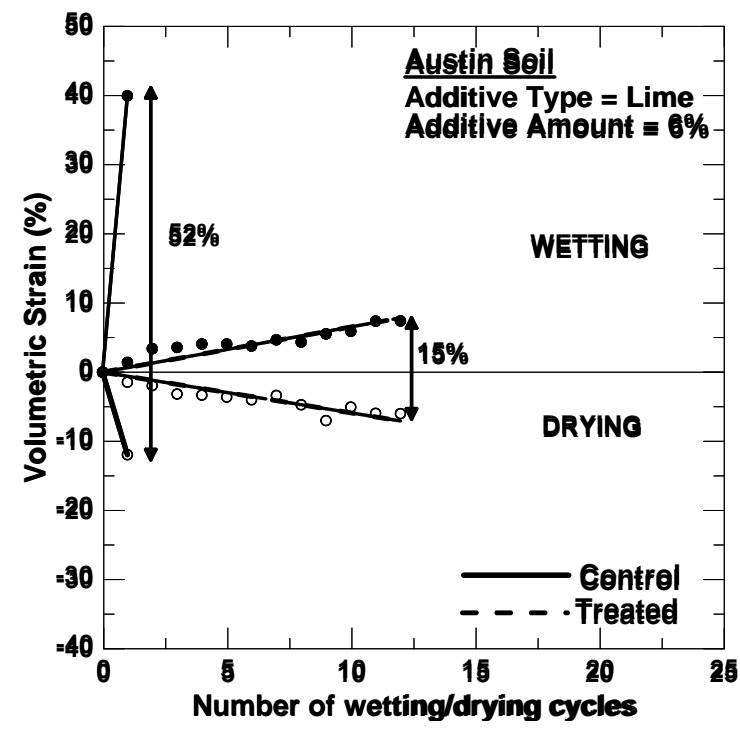

(a)

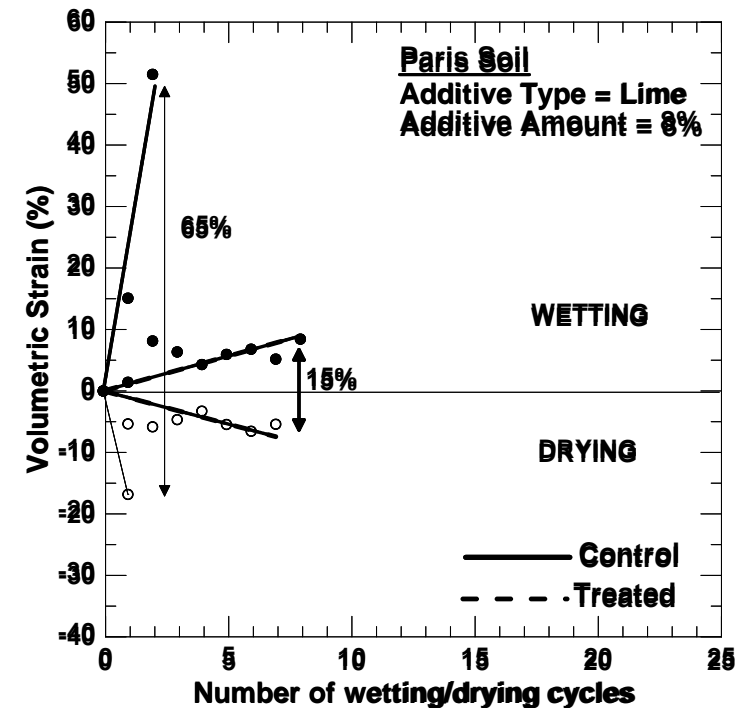

(c)

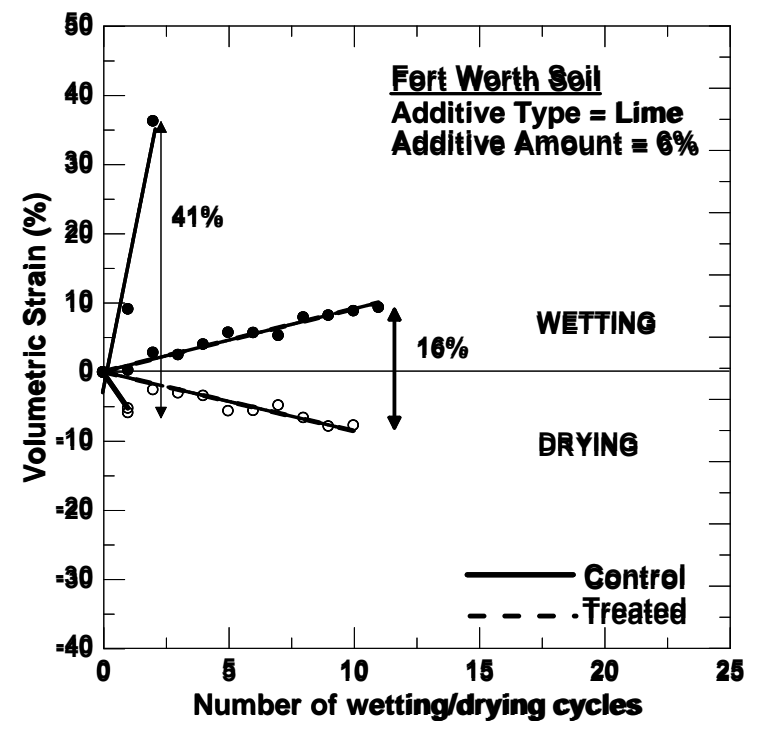

(b)

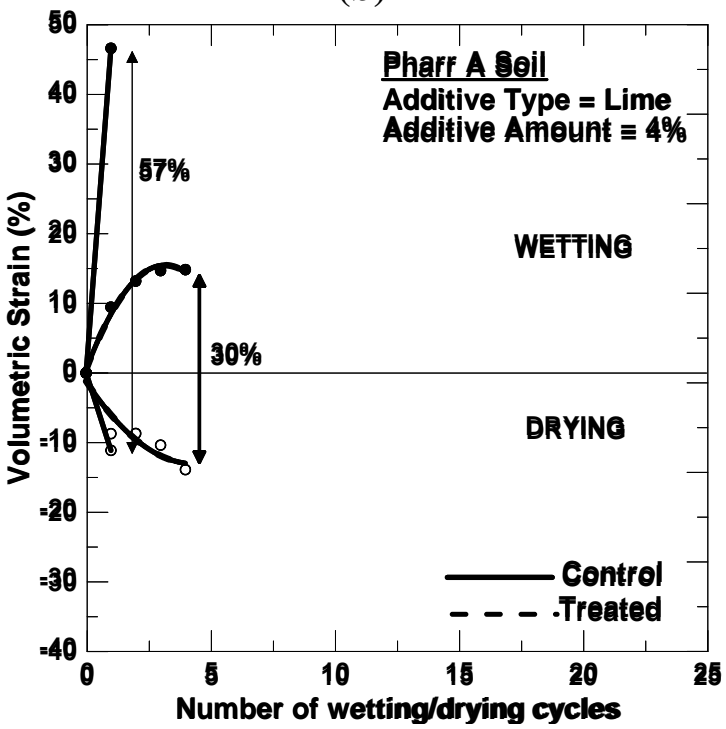

(d)

Figure 2 Volumetric strain change with W/D cycles for Group I soils a) Austin soil b) Fort Worth soil c) Paris soil d) Pharr-A soil 


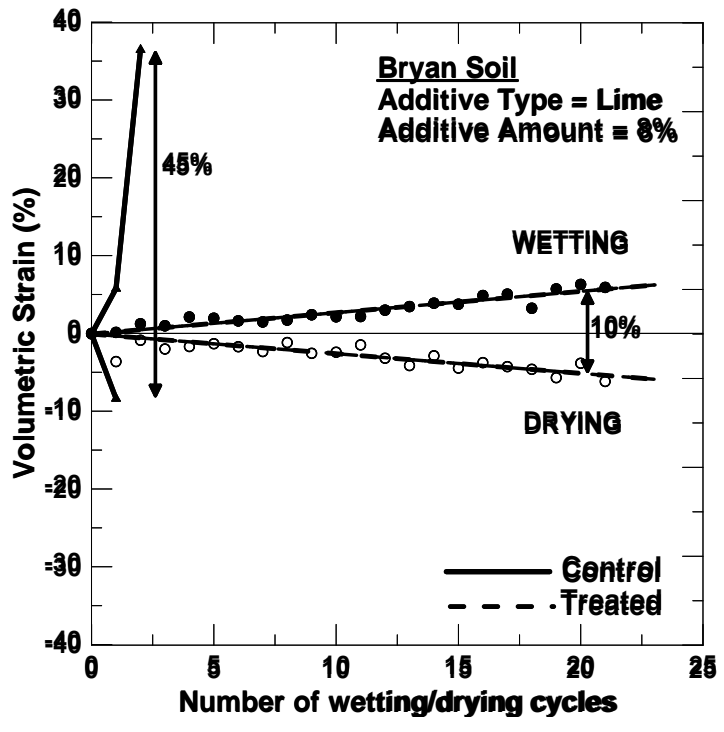

(a)

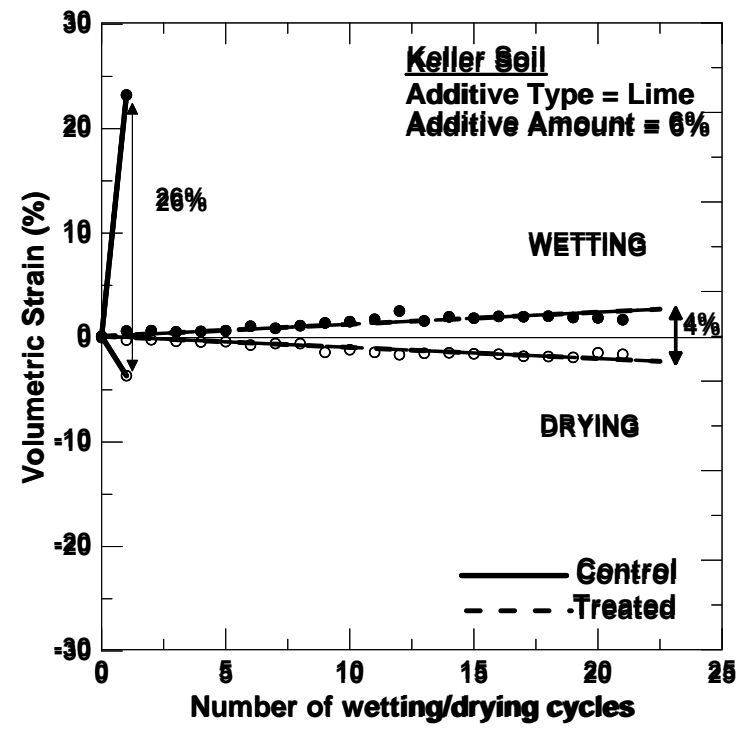

(b)

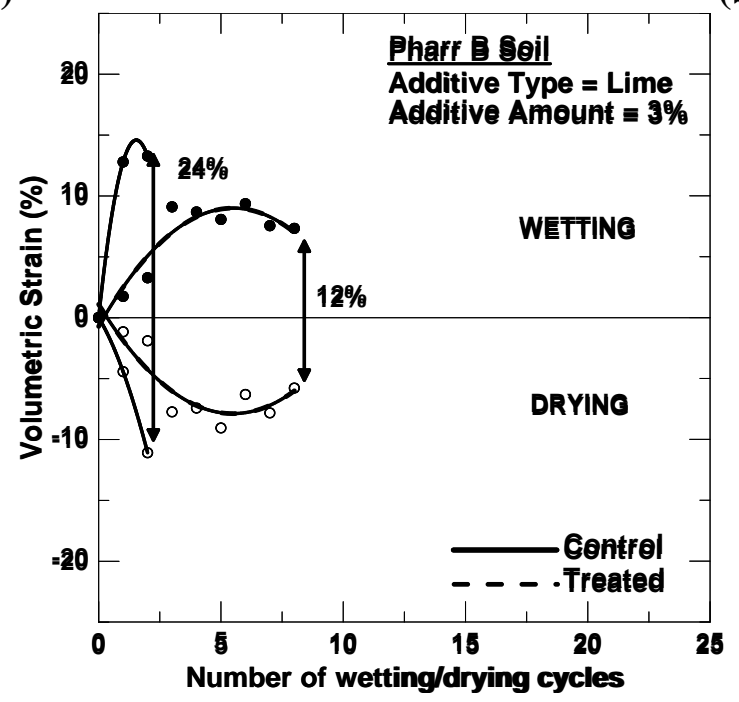

(c)

Figure 3 Volumetric strain change with W/D cycles for Group II soils a) Bryan soil b) Keller soil c) Pharr-B soil 
This is an author-produced, peer-reviewed version of this article. The final, definitive version of this document can be found online at Journal of Geotechnical and Geoenvironmental Engineering, published by the American Society of Civil Engineers. Copyright restrictions may apply. doi: 10.1061/(ASCE)GT.1943-5606.0001796

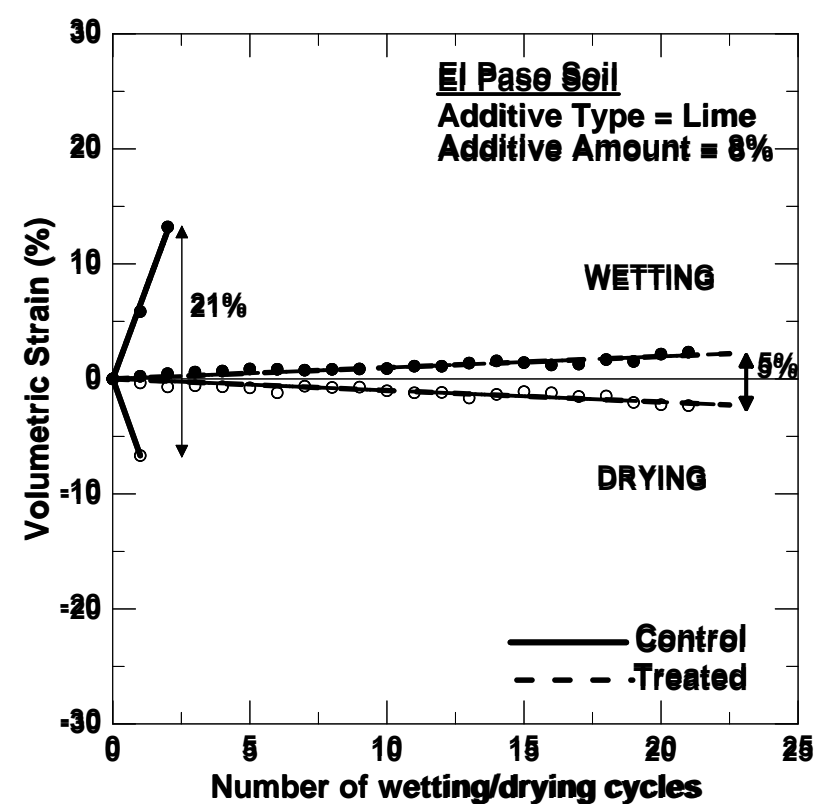

Figure 4 Volumetric strain change with W/D cycles for Group III soil (EI Paso) 


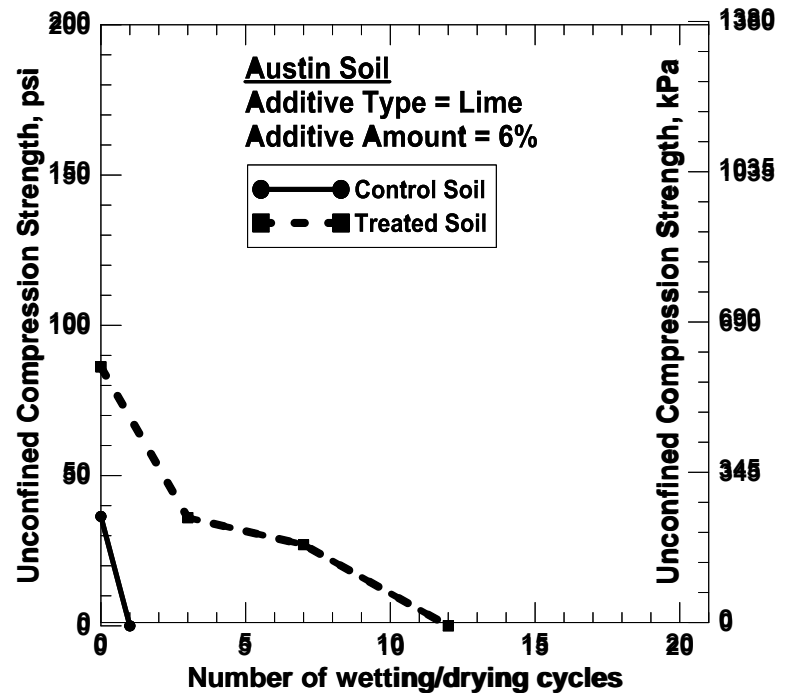

(a)

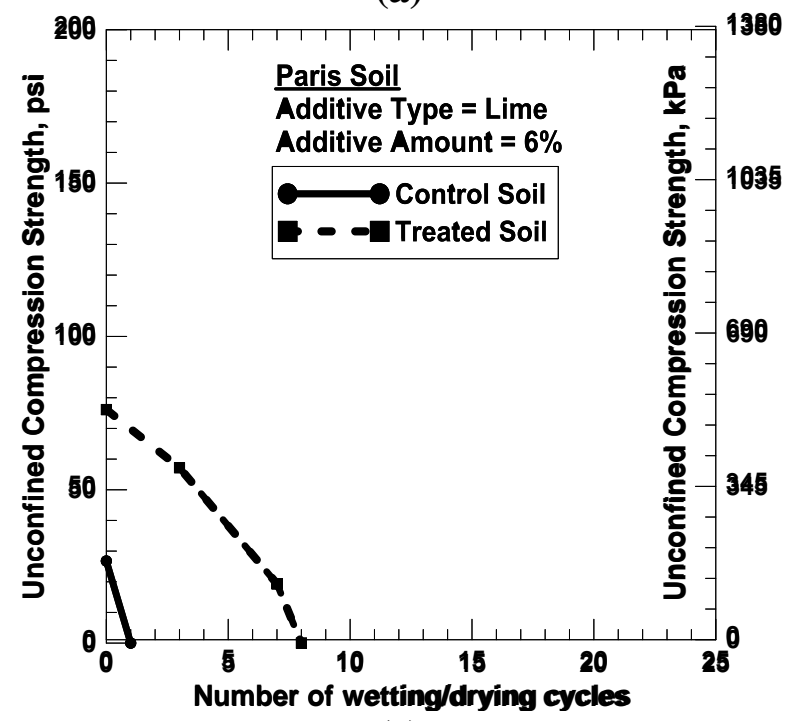

(c)

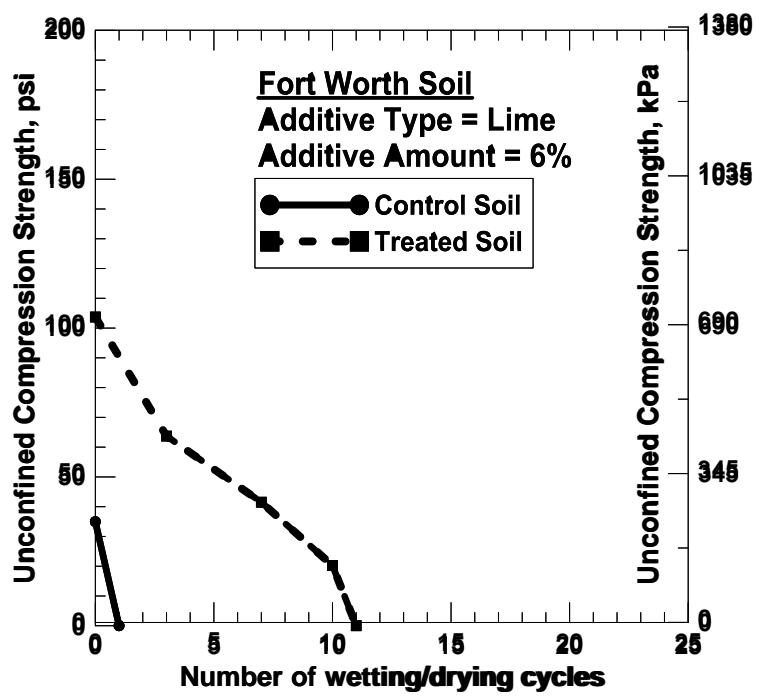

(b)

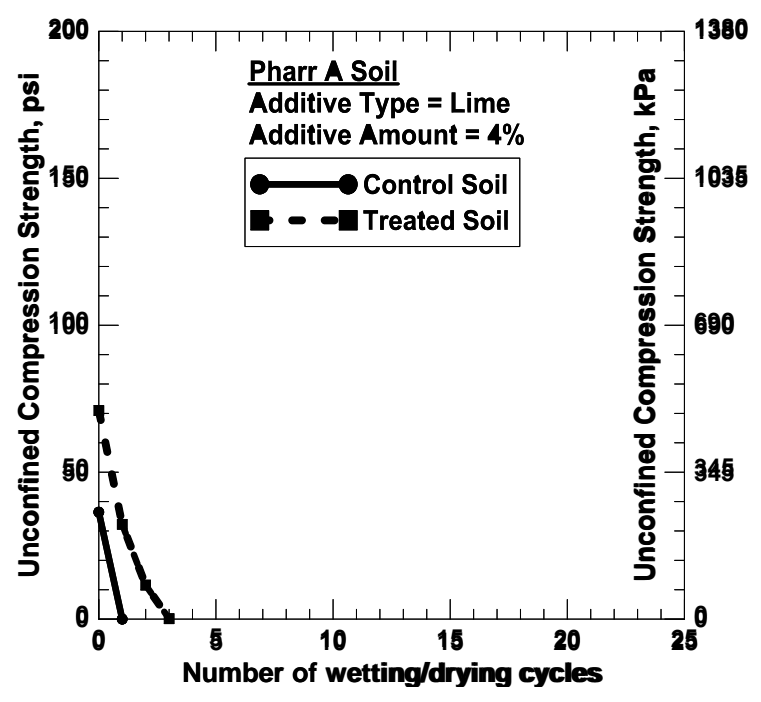

(d)

Figure 5 Unconfined compression strength variation with W/D cycles for Group I soils a) Austin soil b) Fort Worth soil c) Paris soil d) Pharr-A soil 
This is an author-produced, peer-reviewed version of this article. The final, definitive version of this document can be found online at Journal of Geotechnical and Geoenvironmental Engineering, published by the American Society of Civil Engineers. Copyright restrictions may apply. doi: 10.1061/(ASCE)GT.1943-5606.0001796

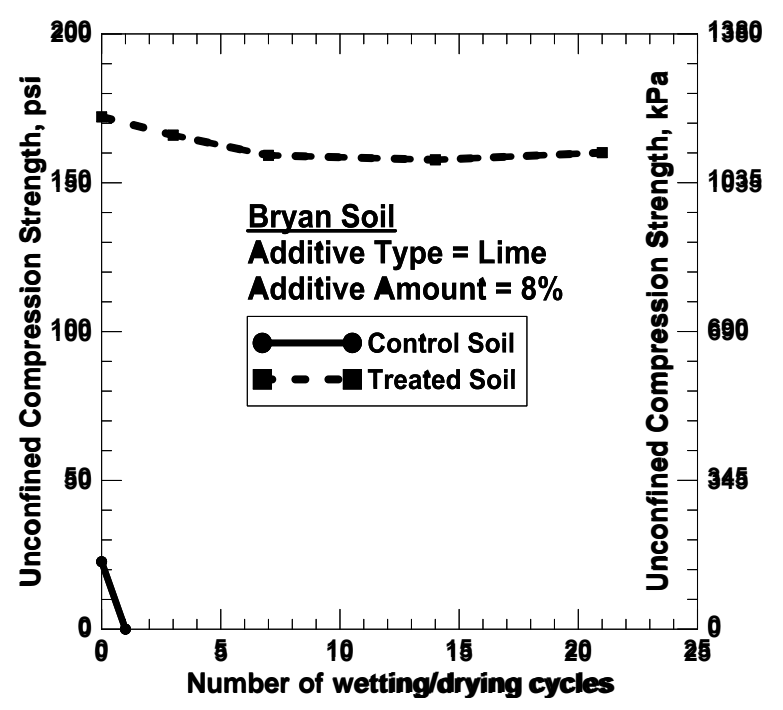

(a)

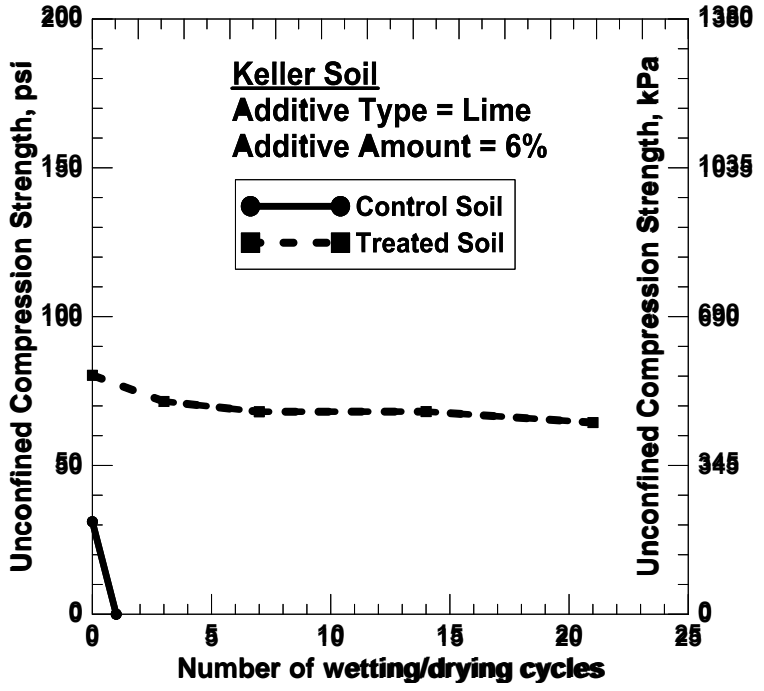

(b)

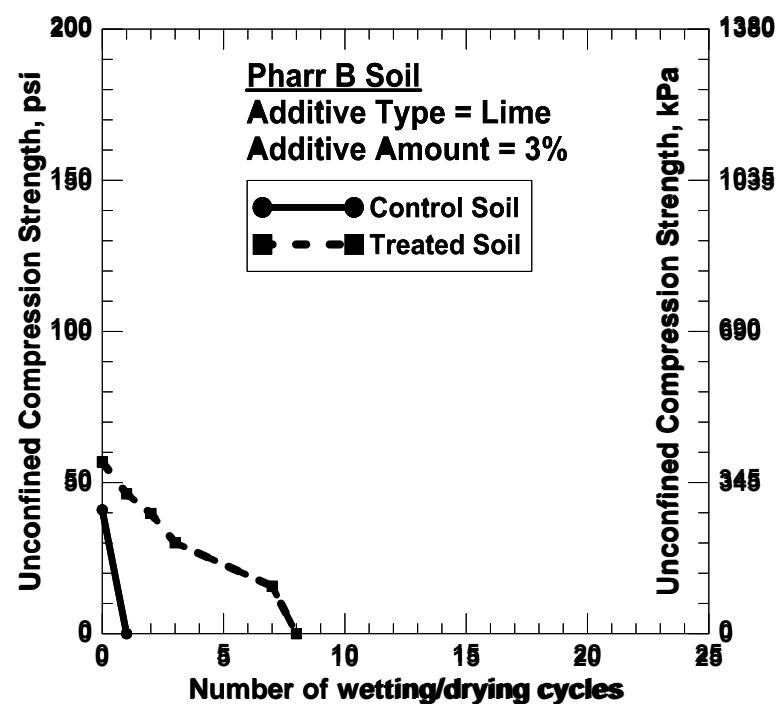

(c)

Figure 6 Unconfined compression strength variation with W/D cycles for Group II soils a) Bryan soil b) Keller soil c) Pharr-B soil 
This is an author-produced, peer-reviewed version of this article. The final, definitive version of this document can be found online at Journal of Geotechnical and Geoenvironmental Engineering, published by the American Society of Civil Engineers. Copyright restrictions may apply. doi: 10.1061/(ASCE)GT.1943-5606.0001796

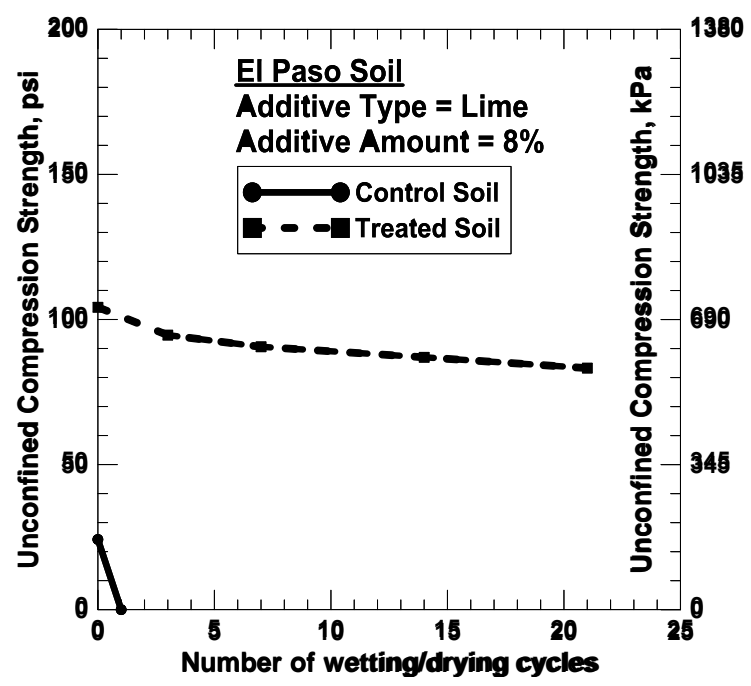

Figure 7 Unconfined compression strength variation with W/D cycles for Group III soil (El Paso) 


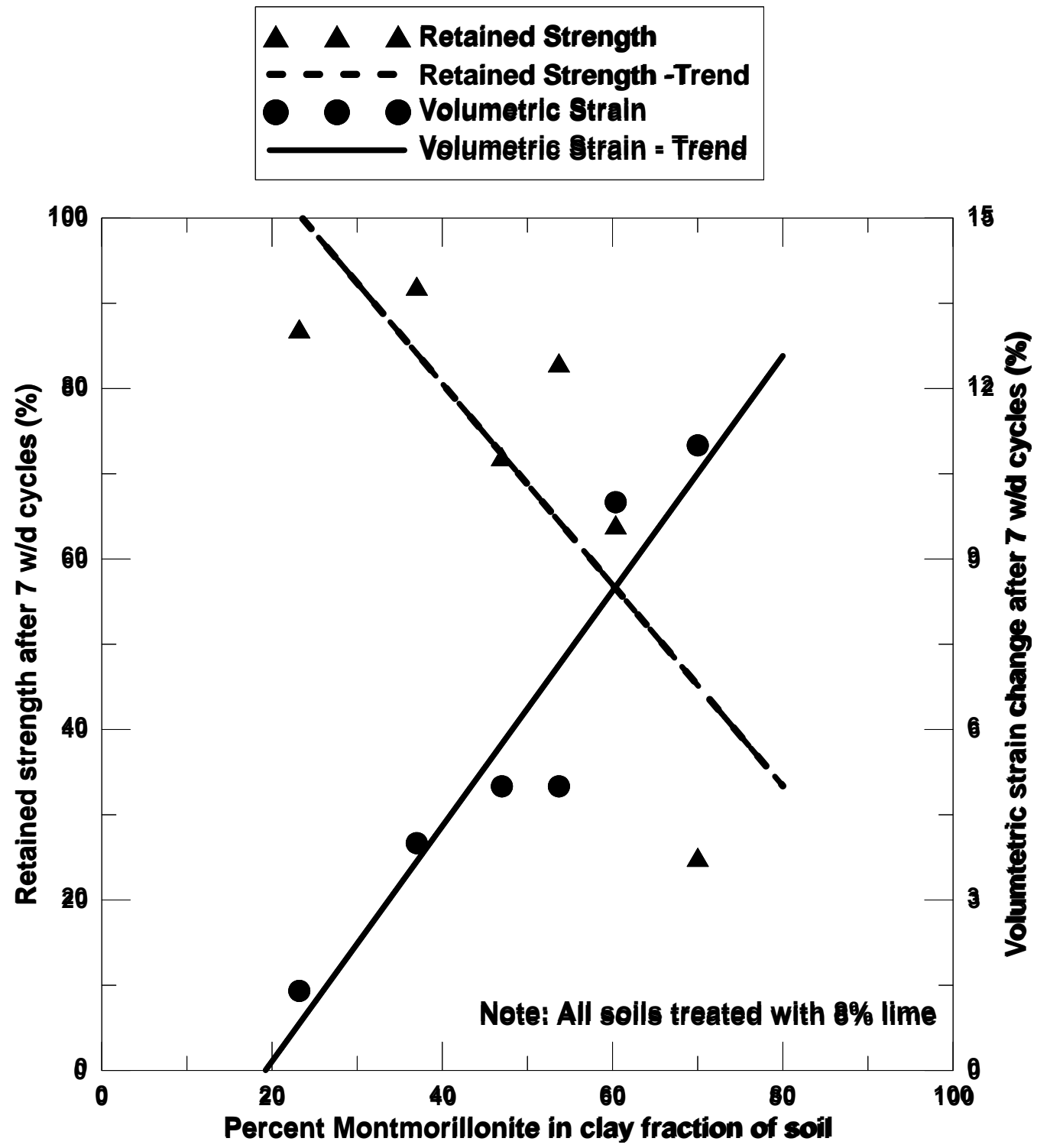

Figure 8 Effect of Montmorillonite mineral on durability lime stabilization 


\section{$\Delta \Delta \Delta$ Retained Strength \\ - - - Retained Strength -Trend \\ - O Volumetric Strain \\ Volumetrie Strain = Frend}

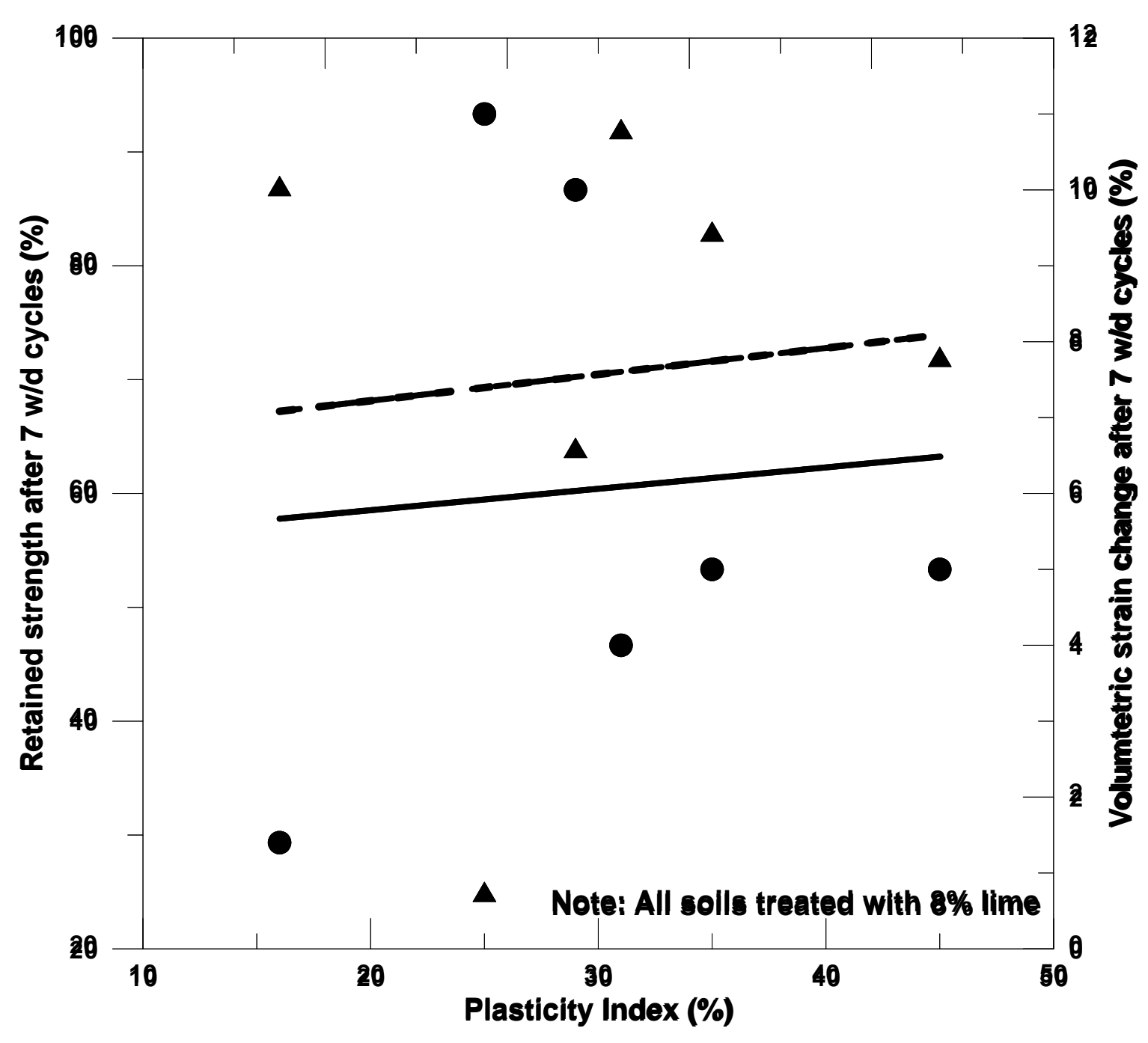

Figure 9 Effect of plasticity index on durability of lime stabilization 


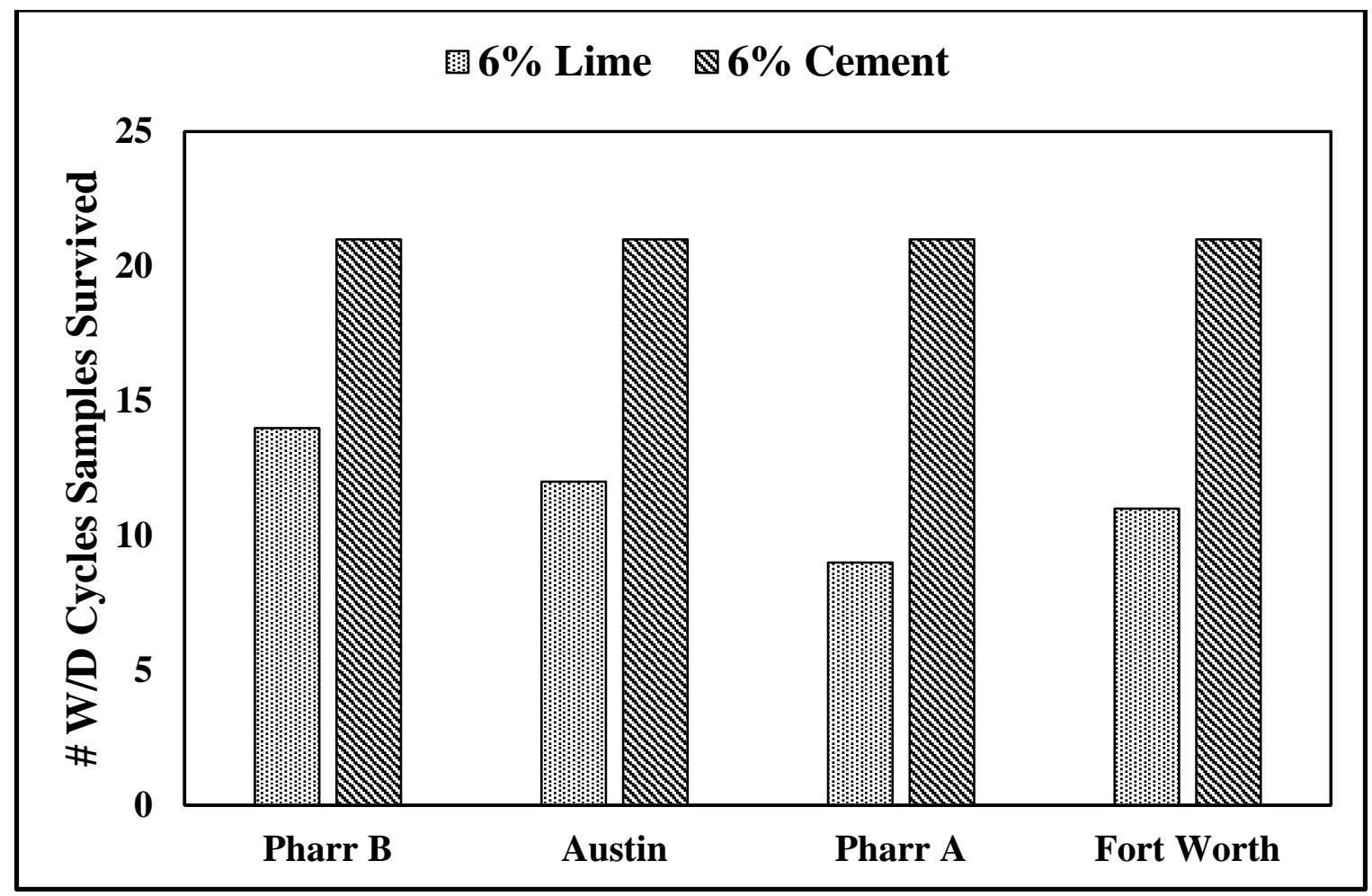

Figure 10 Effect of additive type on the W/D performance of chemical stabilization 

of Geotechnical and Geoenvironmental Engineering, published by the American Society of Civil Engineers. Copyright restrictions may apply. doi: 10.1061/(ASCE)GT.1943-5606.0001796

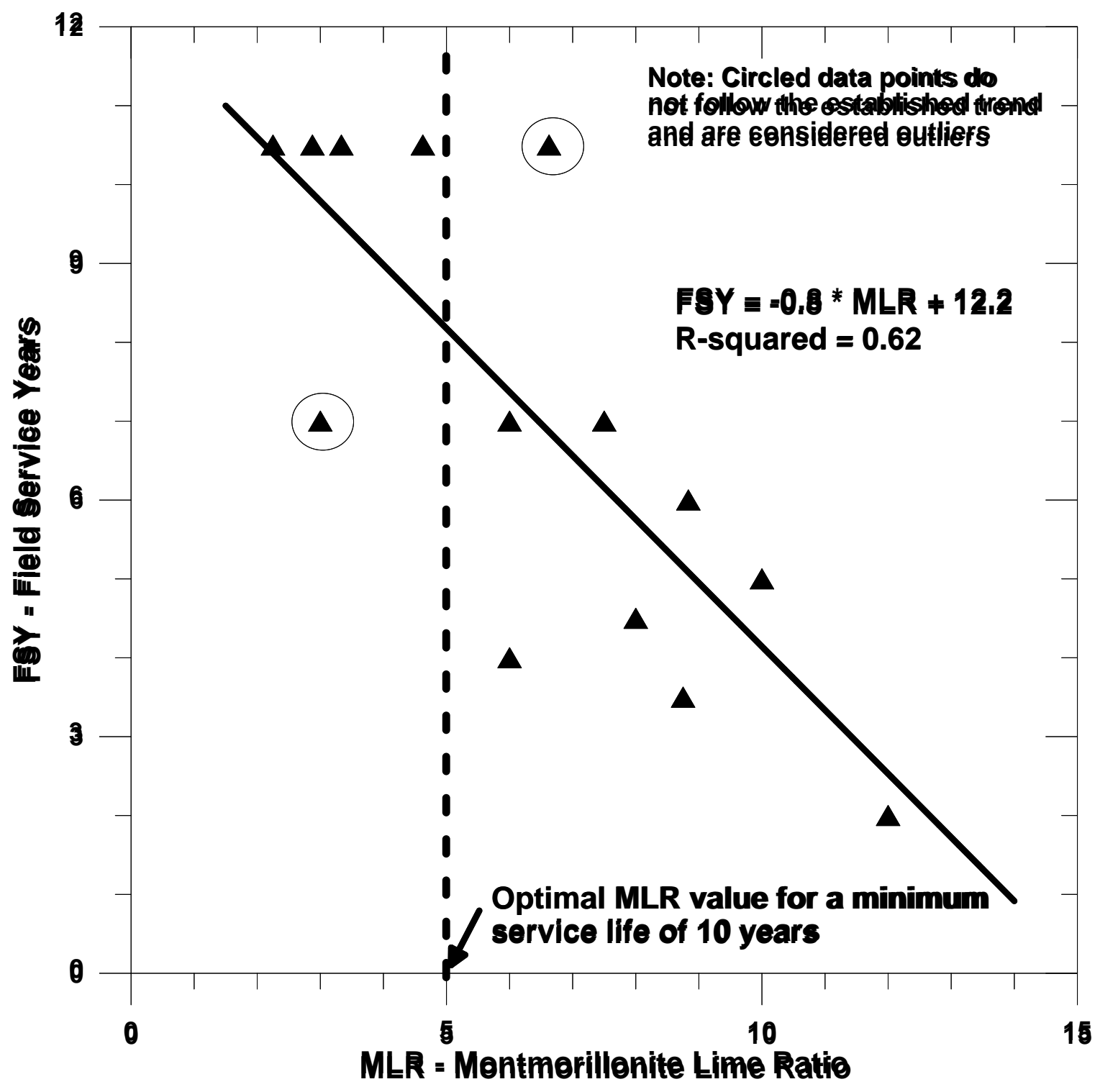

Figure 11 MLR based FSY predictions for the tested soils 